\title{
Crystal Structure, Thermal Analysis, Spectroscopic Studies and DFT Calculations on Hexaaquamagnesium(II) Acesulfamate
}

\author{
Hekzaaquamagnezyum(II) Asesulfamat Molekülünün Kristal \\ Yapısı, Termal Analizi, Spektroskopik Çalışmaları ve DFT
}

\section{Research Article}

Ömer Yurdakul', Güneş Demirtaş² ${ }^{2}$ Necmi Dege ${ }^{3}$, Hasan İçbudak ${ }^{4}$, Dursun Ali Köse ${ }^{1 *}$, Orhan Büyükgüngör ${ }^{3}$

${ }^{1} H$ itit University, Faculty of Arts and Sciences, Department of Chemistry, Çorum, Turkey.

${ }^{2}$ Dr. Sedat-Dr. Melehat Baran Secondary School, Sungurlu, Çorum, Turkey.

${ }^{3}$ Ondokuz Mayıs University, Faculty of Arts and Sciences, Department of Physics, Samsun, Turkey.

${ }^{4}$ Ondokuz Mayıs University, Faculty of Arts and Sciences, Department of Chemistry, Samsun, Turkey.

\section{A B S T R AC T}

\begin{abstract}
The crystal structure of the complex, $\left[\mathrm{Mg}\left(\mathrm{H}_{2} \mathrm{O}\right)_{6}\right]\left(\mathrm{C}_{4} \mathrm{H}_{4} \mathrm{NO}_{4} \mathrm{~S}\right)_{2}$, was determined at $296 \mathrm{~K}$. The unit cell parameters of the crystal structure are $a=6.9404 \AA, b=8.5775 \AA, c=8.7200 \AA, \alpha=68.564^{\circ}, \beta=78.640^{\circ}, \gamma=81.260^{\circ}$ and $Z=1$. The complex crystallizes in the centrosymmetric triclinic space group $\mathrm{P}-1$. $\mathrm{The} \mathrm{Mg}(\mathrm{II})$ ion is coordinated by six $\mathrm{O}$ atoms from six aqua ligands and in the crystal structure, the anions and cations are linked with three dimensions via $\mathrm{O}-\mathrm{H} \cdots \mathrm{O}$ and $\mathrm{O}-\mathrm{H} \cdots \mathrm{N}$ interactions. In addition to the structure which was obtained by $\mathrm{X}$-ray diffraction technique, the theoretical structure was calculated by using density functional theory (B3LYP) with the 6-31G basis sets. The molecular electrostatic potential, frontier molecular orbitals and theoretical IR studies were calculated by using DFT method. Besides, the experimental IR spectrum and thermal analysis were investigated for the complex.
\end{abstract}

\section{Key Words}

Magnesium; DFT Calculations; Coordination Chemistry; Crystal Structure, Thermal Characterization.

\section{ÖZET}

\begin{abstract}
K ompleksin kristal yapısı $\left[\mathrm{Mg}\left(\mathrm{H}_{2} \mathrm{O}\right)_{6}\right]\left(\mathrm{C}_{4} \mathrm{H}_{4} \mathrm{NO}_{4} \mathrm{~S}\right)_{2}, 296 \mathrm{~K}$ 'de tayin edildi. Moleküler Kristal yapının birim hücre N parametreleri $a=6.9404 \AA, b=8.5775 \AA, c=8.7200 \AA, \alpha=68.564^{\circ}, \beta=78.640^{\circ}, \gamma=81.260^{\circ}$ ve $Z=1$ olarak saptanmıştır. Kompleks merkezi simetrik triklinik yapıda kristallenmiş olup uzay grubu P-1'dir. Her bir Mg(II) iyonu altı mol su ligandının $\mathrm{O}$ atomları tarafından koordine edilmiştir. Kristal yapıda anyonlar ve katyonlar $\mathrm{O}-\mathrm{H} \cdots \mathrm{O}$ ve $\mathrm{O}-\mathrm{H} \cdots \mathrm{N}$ etkileşimleriyle üç boyutlu yapıyı oluştururlar. Ilave olarak yoğunluk fonksiyonel teori (DFT) (B3LYP) yönteminin 6-31G temel setleri kullanılarak elde edilen hesaplanmış sonuçlarla deneysel X-ışınları kırınım sonuçları kıyaslanarak moleküler yapı oluşturulmuştur. Moleküler elektrostatik potansiyel, frontier moleküler orbitaller ve IR spektrumu DFT yöntemi kullanılarak hesaplanmıştır. Ayrıca, deneysel IR spektroskopi ve termal analiz yöntemleri ile yapı incelenmiştir.
\end{abstract}

\section{Anahtar Kelimeler}

Magnezyum; DFT Hesaplamaları; Koordinasyon Kimyası; Kristal Yapı; Termal Karakterizasyon.

Article History: Received: Jan 5, 2016; Revised: Mar 17, 2016; Accepted: Mar 20, 2016; Available Online: Apr 01, 2016. DOI: $10.15671 /$ HJBC.20164417570

Correspondence to: D.A. Köse; Hitit University, Faculty of Arts and Sciences, Department of Chemistry, Çorum, Turkey. 


\section{INTRODUCTION}

A cesulfame (acs) is without calorie and has been used as artificial sweetener since 1988 Acesulfame is not digested, accumulated and changed in the human metabolism and it is rapidly excreted from the body [1]. While acesulfame with some ammonium compounds exhibits acute oral toxicities, deterrent activity and causes skin irritation, choline acesulfamate has low toxic character [2,3]. In addition biological importance of acesulfame, its coordination characteristics are also important, since acesulfame has donor atoms which can form coordination bonds with metal ions [4]. Studies belong to the different crystalline forms of acesulfame, which may have different physical, chemical and mechanical properties, have been reported in the literature [5].

The coordination compounds of s-block elements are preferred to transition or lanthanide metal ions, because alkali and alkali earth metals are cheap and soluble in aqueous media and have non-toxic properties [6]. Magnesium, which is very important biologically in alkali earth metals, has been reported in three different states in most biological system. These are bounded to protein, complexed to anion and free [7]. It is fundamental for the regulation of various biological processes. The magnesium deficiency especially may play a crucial role in pathogenesis of ischemic heart disease, cardiomyopathy, and certain arrhythmias [7-11]. In this study, the crystallographic, spectroscopic and theoretical studies of hexaaquamagnesium(II) acesulfamate complex was handled.

\section{Experimental}

\section{Material Methods}

All chemicals were obtained from SigmaAldrich and used without purfication. Elemental analysis $(\mathrm{C}, \mathrm{H}, \mathrm{N})$ were carried out by standard methods (Tubitak Marmara Research Center). IR spectra were recorded in the $4000-400 \mathrm{~cm}^{-1}$ region with a Perkin Elmer Spectrum One FTIR spectrophotometer using $\mathrm{KBr}$ pellets. Thermal analyses (TGA, DTA) were performed by the
Shimadzu DTG-60H system, in dynamic nitrogen atmosphere $(100 \mathrm{~mL} / \mathrm{min})$ at a heating rate of $10^{\circ} \mathrm{C} /$ min, in platinum crucibles as sample vessel, using $\alpha-\mathrm{Al}_{2} \mathrm{O}_{3}$ as reference. Mass spectra was recorded Thermo Scientific DSQ II Single Quadrupole GC/ $\mathrm{MS}$ in the electron impact (EI) ionisation mode (70 eV) and HP- 5MS (bonded and cross-linked $5 \%$ phenyl-methylpolysiloxane, $30 \mathrm{~mm} \times 0.25$ $\mathrm{mm}$, coating thickness $0.25 \mu \mathrm{m}$ ) capillary column (Restek, Bellefonte, PA). The single XRD data was collected by a STOE IPDS II diffractometer equipped with a graphite-monochromatic Mo-Ka radiation $(\lambda=0.71073 \AA$ ) at $296 \mathrm{~K}$.

\section{Synthesis of Metal-Acesulfame (ace) Complexes}

A hot solution $\left(60^{\circ} \mathrm{C}\right)$ of acesulfame potassium salt $(8 \mathrm{mmol}, 1.610 \mathrm{~g}$ ) in distilled water (50 $\mathrm{mL}$ ) was gradually added to a hot stirring solution of magnesium perchlorate dihydrate $\left(\mathrm{Mg}\left(\mathrm{ClO}_{4}\right)_{2} \cdot 2 \mathrm{H}_{2} \mathrm{O}\right)(4 \mathrm{mmol}, 1.037 \mathrm{~g})$ in distilled water $(50 \mathrm{~mL})$. The obtained mixture was stirred on a hot plate with slow evaporation to dryness at $70^{\circ} \mathrm{C}$. The complex was extracted with absolute ethanol from the resulting precipitate consisting of both itself and $\mathrm{KClO}_{4}$ salt according to the below reaction scheme.

$2 \mathrm{C}_{9} \mathrm{H}_{5} \mathrm{O}_{3} \mathrm{~K}(\mathrm{aq})+\mathrm{M}\left(\mathrm{ClO}_{4}\right)_{2}(\mathrm{aq}) \rightarrow \mathrm{Mg}\left(\mathrm{C}_{9} \mathrm{H}_{5} \mathrm{O}_{3}\right)_{2}(\mathrm{aq})+2 \mathrm{KClO}_{4}$

The final ethanolic solution was left for crystallization and in a few days, the crystals of $\mathrm{X}$-ray quality were obtained by slow evaporation from the solution at room temperature.

\section{Theoretical Study}

The geometrical parameters were calculated using the Gaussian 03 program package and B3LYP approach in conjunction with the 6-31G $(d, p)$ basis set [12]. For modeling, the $X$-ray coordinates were used as the initial values.

For the harmonic vibrational frequencies, the same level of theory had been used for finding the optimized structure and the obtained frequencies were scaled by 0.9627 [13]. The vibrational bands assignments were made by using Gauss-View molecular visualization program [14]. 
Table 1. Analytical data of Mgll and Call complexes.

\begin{tabular}{|c|c|c|c|c|c|c|c|c|c|c|}
\hline Compound & $\begin{array}{c}\mathrm{MA} \\
(\mathrm{g} / \mathrm{mol})\end{array}$ & $\begin{array}{l}\text { m.p.* } \\
\left({ }^{\circ} \mathrm{C}\right)\end{array}$ & \multicolumn{2}{|c|}{ C (\%) } & \multicolumn{2}{|c|}{$\mathrm{H}(\%)$} & \multicolumn{2}{|c|}{ N (\%) } & \multicolumn{2}{|c|}{ S (\%) } \\
\hline \multirow{2}{*}{$\mathrm{C}_{8} \mathrm{H}_{20} \mathrm{MgN}_{2} \mathrm{O}_{14} \mathrm{~S}_{2}$} & \multirow{2}{*}{456.69} & \multirow{2}{*}{95} & Calc. & Found & Calc. & Found & Calc. & Found & Calc. & Found \\
\hline & & & 21.93 & 21.04 & 5.26 & 4.40 & 6.07 & 6.14 & 14.04 & 13.72 \\
\hline
\end{tabular}

\section{RESULT and DISCUSSION}

The analytical data of complexes were given in Table 1. The yield of compounds are about $82 \%$ for Mgll complex and $87 \%$ for Call complex.

\section{X-Ray Crystal Structure Determination}

Single-crystal X-ray data were collected on a Stoe IPDS II single crystal diffractometer using monochromated MoK $\alpha$ radiation at 296 K. X-AREA and $X-R E D$ programs were used to cell refinement and data reduction, respectively [15]. SHELXS-97 and SHELXL-97 programs were used to solve and refine the structure, respectively [16]. ORTEP-3 for Windows was used to preparation the figures [17]. WinGX and PLATON software were used to prepare material for publication $[18,19]$. The same molecular structure $\mathrm{C}_{8} \mathrm{H}_{20} \mathrm{MgN}_{2} \mathrm{O}_{14} \mathrm{~S}_{2}$, explained by Piro and co-authours [20], the single crystal structure of $\mathrm{C}_{8} \mathrm{H}_{20} \mathrm{MgN}_{14} \mathrm{~S}_{2}$ was studied again for compare with theoretical results.

All of the hydrogen atoms were positioned freely. The $\mathrm{C}-\mathrm{H}$ bond distances are 0.95 (2) $\AA$, 0.95 (3) $\AA$ and 0.91 (3) $\AA$ for methyl group and 0.93 (2) $\AA$ for aromatic $\mathrm{C}-\mathrm{H}$. The $\mathrm{O}-\mathrm{H}$ bond distances range from 0.79 (3) $\AA$ to 0.87 (3) $\AA$ for aqua ligands. The refinement parameters of the crystal structure are given in Table 2.

The hexaaquamagnesium(II) acesulfamate molecule crystallizes in the centrosymmetric triclinic space group $\mathrm{P}-1$. The unit cell of the complex contains one $\left[\mathrm{Mg}\left(\mathrm{H}_{2} \mathrm{O}\right)_{6}\right]^{2+}$ dication and two (acs) ${ }^{-}$anions. As can be seen in Figure 1 , the $\mathrm{Mg}^{2+}$ ion has six-coordination by six $\mathrm{O}$ atoms from six aqua ligands and the environment of $\mathrm{Mg}^{2+}$ has distorted octahedron geometry. The $\mathrm{Mg}-\mathrm{O}$ bond distances range from 2.0445 (11) $\AA$ to 2.0817 (12) $\AA$. These values are consistent with the literature [21-23]. The $\mathrm{C} 1-\mathrm{N} 1$ and $\mathrm{C} 1-$ 04 bond distances and $\mathrm{C} 1-\mathrm{N} 1-\mathrm{S} 1$ bond angle are 1.3448 (19) $\AA, 1.2472$ (18) $\AA$ and 119.71 (10) $^{\circ}$, respectively. The bond distances and bond angles of some acs complexes have been reported for [Ni(acs) ${ }_{2}\left(\mathrm{H}_{2} \mathrm{O}\right)_{4}$ ] [4] (i.e., the $\mathrm{C} 1-\mathrm{N} 1, \mathrm{C} 1-\mathrm{O} 1$ and $\mathrm{C} 1-$ N1-S1 are 1.338 (2) $\AA, 1.258$ (2) $\AA$ and $\left.118.66(10)^{\circ}\right)$, for $\left[\mathrm{Cu}\left(\mathrm{C}_{4} \mathrm{H}_{4} \mathrm{NO}_{4} \mathrm{~S}\right)_{2}\left(\mathrm{C}_{4} \mathrm{H}_{5} \mathrm{~N}_{3}\right)_{2}\right.$ ] [24] (i.e., the $\mathrm{C} 1-\mathrm{N} 1$ and $\mathrm{C} 1-01$ are 1.333 (3) $\AA$ and 1.274 (2) $\AA$ ), for $\left[\mathrm{Co}\left(\mathrm{C}_{4} \mathrm{H}_{4} \mathrm{NO}_{4} \mathrm{~S}\right)_{2}\left(\mathrm{H}_{2} \mathrm{O}\right)_{4}\right]$ [25] (i.e., the $\mathrm{C} 1-\mathrm{N} 1, \mathrm{C} 1-\mathrm{O} 1$ and $\mathrm{C} 1-\mathrm{N} 1-\mathrm{S} 1$ are 1.361 (3) $\AA, 1.251$ (3) $\AA$ and 117.65 $\left.(16)^{\circ}\right)$, for $\left[\mathrm{Cd}_{2}\left(\mathrm{C}_{4} \mathrm{H}_{4} \mathrm{NO}_{4} \mathrm{~S}\right)_{2}\left(\mathrm{C}_{6} \mathrm{H}_{7} \mathrm{~N}\right)_{2}\right.$ ] [26] (i.e., the C17-05 and $\mathrm{C} 13-04$ are 1.254 (3) $\AA$ and 1.244 (4) $\AA$ ), for $\left[\mathrm{Cu}(\mathrm{dmen})_{2}\left(\mathrm{H}_{2} \mathrm{O}\right)_{2}\right](\mathrm{acs})_{2}$ [27] (i.e., the C5N3-S is $\left.123.0(2)^{\circ}\right),\left[\mathrm{Ca}_{2}(\mathrm{acs})_{2}\left(\mathrm{H}_{2} \mathrm{O}\right)_{2}(\mathrm{acs})_{2}\right] \mathrm{n}$ [28] (i.e., the C4 N1, C5 N2, C4 N1 S1, C5 N2 S2 are 1.334 (2) $\AA, 1.337$ (2) $\AA, 119.18(11)^{\circ}$ and 119.09 (11) $^{\circ}$, respectively). The $\mathrm{O}-\mathrm{Mg}-\mathrm{O}$ bite angles of the complex range from $88.59(5)^{\circ}$ to $180.00(7)^{\circ}$.

In the crystal structure, (acs) ${ }^{-}$anions and water molecules are linked through $\mathrm{O}-\mathrm{H} \cdots \mathrm{O}$ and $\mathrm{O}-\mathrm{H} \cdots \mathrm{N}$ hydrogen bonds into three dimensions framework. The geometric parameters of some hydrogen bonds are 0.84 (3) $\AA, 1.85$ (3) $\AA, 2.6909$ (18) $\AA$ and 177 (3) ${ }^{\circ}$ for $05-\mathrm{H} 5 \mathrm{~A} \cdots 04 ; 0.84$ (3) $\AA, 1.86$ (3) $\AA, 2.6960$ (19) $\AA$ and 173 (2) ${ }^{\circ}$ for 07H7B $\cdots 04$, respectively. The detailed geometric parameters of hydrogen bonds are given in Table 3.

As can be seen in Figure 2, the $\left[\mathrm{Mg}\left(\mathrm{H}_{2} \mathrm{O}\right)_{6}\right]^{2+}$ dications settle to the corner of unit cell, while the (acs) ${ }^{-}$anions are settling to the center of unit cell. These anions and cations are linked through hydrogen bonds in the crystal structure.

In complex cation, the Mg1-05, Mg1-06 and Mg1-07 bond distances are 2.0445 (11) $\AA$, 2.0644 (12) $\AA$ and 2.0817 (12) $\AA$, respectively. Because 
Table 2. Crystal data and structure refinements of the complex.

\begin{tabular}{|c|c|}
\hline Formula & $\mathrm{C}_{8} \mathrm{H}_{2} \mathrm{OMgN}_{2} \mathrm{O}_{14} \mathrm{~S}_{2}$ \\
\hline Formula weight & 456.69 \\
\hline Crystal system & Triclinic \\
\hline Space group & $P-1$ \\
\hline \multicolumn{2}{|l|}{ Unit cell Dimensions $\left(\AA,{ }^{\circ}\right)$} \\
\hline$a, b, c$ & 6.9404 (8), $8.5775(11), 8.7200$ (12) \\
\hline$\alpha, \beta, \gamma$ & $68.564(10), 78.64(1), 81.26(1)$ \\
\hline Volume $\left(\AA^{3}\right), Z$ & $471.92(10), 1$ \\
\hline$F(000)$ & 238 \\
\hline Range for collection data $\left({ }^{\circ}\right)$ & $2.54-27.41$ \\
\hline Limiting indicates & $-8 \leq h \leq 8 ;-10 \leq k \leq 10 ;-10 \leq \mathrm{I} \leq 10$ \\
\hline Collected Reflections & 8556 \\
\hline Independent reflections & {$[R($ int $)=0.0431] 1858$} \\
\hline Completeness (\%) & 100 \\
\hline Goodness-of-fit on $\mathrm{F}^{2}$ & 1.0880 \\
\hline Final $R$ indices $[I>2 \sigma(I)]$ & $R_{1}=0.027 ; w R_{2}=0.076$ \\
\hline $\mathrm{R}$ indices (all data) & $\mathrm{R}_{1}=0.031 ; \quad w R_{2}=0.078$ \\
\hline
\end{tabular}

Figure 1. ORTEP diagram of the title compound, showing the atomic numbering scheme. Displacement ellipsoids are drawn at the $50 \%$ probability level. $i=-x,-y,-z$. 


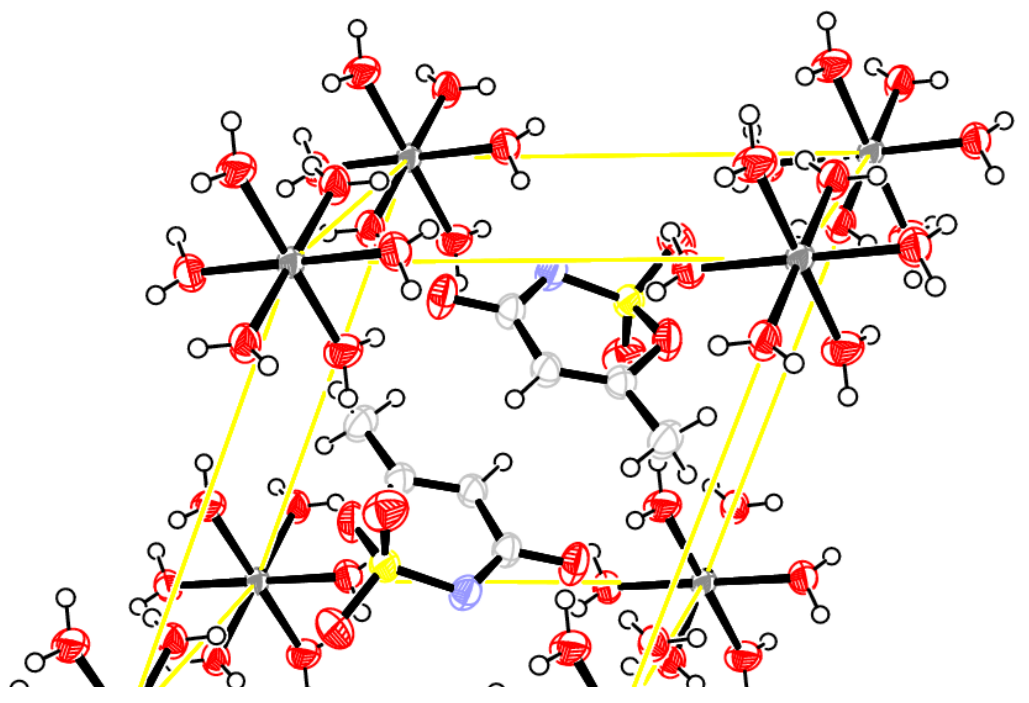

Figure 2. The crystal packing of the title compound in the unit cell.
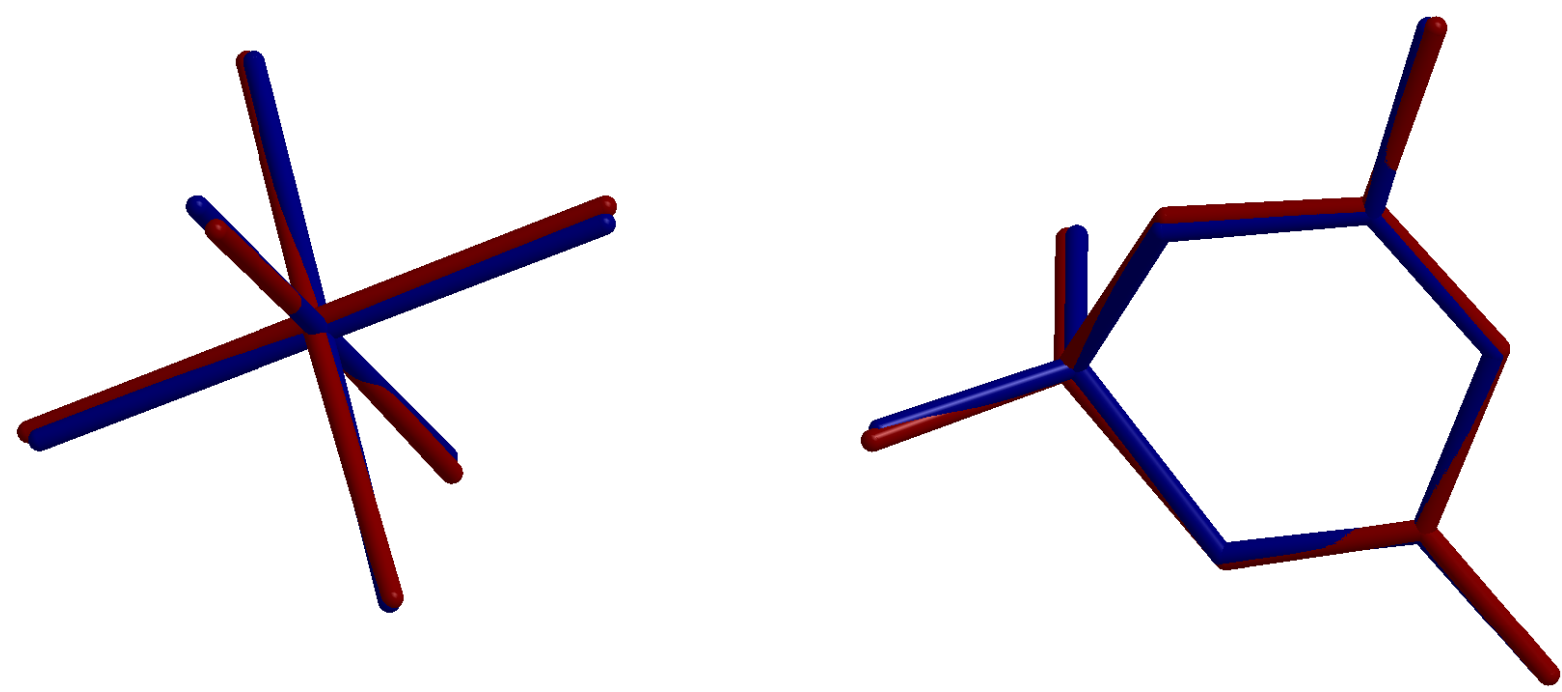

Figure 3. Atom-by-atom superimposition of the structures calculated (red) (DFT B3LYP/6-31G(d,p)) on the x-ray structure (blue) of the title compound (r.m.s.=1.569). Hydrogen atoms have been omitted for clarity.

of these bond distances are almost equal, the environment of $\mathrm{Mg}^{2+}$ ion deviates very little from octahedron geometry.

\section{Theoretical Results}

While the least difference between experimental and theoretical bond distances is between $\mathrm{C} 1$ and $\mathrm{N} 1$ atoms with $0.0001 \AA$, the biggest difference between experimental and theoretical bond distances is between 03 and $\mathrm{S} 1$ atoms with 0.1261 $\AA$. The experimental (blue) and theoretical (red) structures of the complex are given in Figure
3. The theoretical and experimental molecular geometries are approximately superposed.

In the crystal structure, the experimental and theoretical $\mathrm{Mg}-\mathrm{O}$ bond distances are found 2.0445 (11) $\AA$ and $2.1456 \AA$ for Mg1-05i; 2.0445 (11) $\AA$ and $2.1055 \AA$ for Mg1-05; 2.0644 (12) $\AA$ and $2.1006 \AA$ for Mg1-06i; 2.0644 (12) $\AA$ and $2.119 \AA$ for Mg1-06; 2.0817 (12) $\AA$ and $2.117 \AA$ for Mg1-07i; 2.0817 (12) $\AA$ and $2.099 \AA$ for Mg1-07, respectively. Although the $\mathrm{Mg}-\mathrm{O}$ bond distances defined by $\mathrm{X}$-ray diffraction technique equal 
to each other symmetrically, the $\mathrm{Mg}-\mathrm{O}$ bond distances calculated by DFT method are different from each other symmetrically, due to only one molecule was calculated by DFT. If bond angles are considered, the biggest difference between experimental and theoretical bond angles are found for 05-Mg1-06i with $13.4619^{\circ}$. The least difference between experimental and theoretical bond angles are found for $01-\mathrm{S} 1-03$ with $0.0112^{\circ}$ The experimental and theoretical bond distances, bond angles, torsion angles and the error quantities between experimental and theoretical values are given in Table 4.

While the biggest difference between experimental and theoretical torsion angles is found for $\mathrm{C} 3-03-\mathrm{S} 1-01$ with $6.0164^{\circ}$, the least difference between experimental and theoretical torsion angles is found of $\mathrm{C} 1-\mathrm{N} 1-\mathrm{S} 1-\mathrm{O} 2$ with $0.9412^{\circ}$.

In this study, we looked accordance between theoretical and experimental values and couldn't find large difference between the theoretical and experimental values.

\section{Frontier Molecular Orbitals}

The LUMO+1, LUMO, HOMO, HOMO-1 orbitals were calculated for the complex and the energy levels with distributions of these molecular orbitals were given in Figure 4. While $\mathrm{HOMO}$ and LUMO+1 are not localized on acs ligand, HOMO-1 is only localized on acs ligand. Electrons are delocalized on the water molecules that surrounded $\mathrm{Mg}^{2+}$ ion at HOMO and LUMO+1 orbitals. The energy gap between HOMO and LUMO is $1.3984 \mathrm{eV}$.

\section{Molecular Electrostatic Map}

The molecular electrostatic potential map (MEP) was calculated for the structure which is optimized with B3LYP/6-31G $(d, p)$. The values of MEP which correspond to the surface determined from points with electronic density $(\rho) 0.0004$ a.u. were used. The negative regions of the MEP are related to electrophilic reactivity and positive regions are related to nucleophilic reactivity.

Molecular electrostatic potential (MEP) indicates electrophilic and nucleophilic attack centers as well as intermolecular interactions such as hydrogen bonding interactions $[29,30]$ As shown in Figure 5, the molecule has a few nucleophilic attack centers. The maximum nucleophilic regions are at the environment of H5A and H7A atoms with approximately 0.0605 a.u. and 0.0531 a.u., respectively. The electrophilic regions for the molecule are at the environment of 01 and 02 atoms with approximately -0.0591 a.u. and -0.0605 a.u., respectively. The crystal structure has six hydrogen bonds, all of these hydrogen bonds which are between $\left[\mathrm{Mg}\left(\mathrm{H}_{2} \mathrm{O}\right)_{6}\right]^{2+}$ dications and (acs) ${ }^{-}$anions are concentrated at vicinity of nucleophilic attack center and electrophilic attack center. Additionally, the dipole moment and total energy of the title compound were found as 7.0927 D and -1567.4032 a.u.

\section{Vibrational Spectrum}

The theoretical and experimental vibrational frequencies of the hexaaquamagnesium(II) acesulfamate between $550 \mathrm{~cm}^{-1}$ and $4000 \mathrm{~cm}^{-1}$ are seen in Figure 6.

Theoretical stretching frequencies for $\mathrm{H}_{2} \mathrm{O}$ molecules range also from $3014.98 \mathrm{~cm}^{-1}$ to $3689.18 \mathrm{~cm}^{-1}$. These stretching vibrational frequencies are observed as broaden curve at around $3570 \mathrm{~cm}^{-1}$ and $3546 \mathrm{~cm}^{-1}$ experimentally. Theoretical scissoring frequencies for $\mathrm{H}_{2} \mathrm{O}$ molecules range from $1467.27 \mathrm{~cm}^{-1}$ to $1658.57 \mathrm{~cm}^{-1}$. Hydrogen bonds are a very important effect in infrared spectroscopy [31] and the aqua ligands surrounded $\mathrm{Mg}^{2+}$ ion make many hydrogen bonds with other molecules, therefore the spectrum is broaden. Theoretical stretching vibrational frequencies belong to $\mathrm{C}=\mathrm{O}$ and $\mathrm{C}=\mathrm{C}$ were found at $1468.62 \mathrm{~cm}^{-1}$ and $1614.33 \mathrm{~cm}^{-1}$, respectively. The experimental spectrum for $\mathrm{C}=\mathrm{O}$ and $\mathrm{C}=\mathrm{C}$ may be at about $1655 \mathrm{~cm}^{-1}$ and $1554 \mathrm{~cm}^{-1}$. The carbonyl stretching band of $\mathrm{K}(\mathrm{acs}),\left[\mathrm{Co}(\mathrm{acs})_{2}\left(\mathrm{H}_{2} \mathrm{O}\right)_{4}\right.$ ] and [Ni(acs) ${ }_{2}\left(\mathrm{H}_{2} \mathrm{O}\right)_{4}$ ] had been found at $1661 \mathrm{~cm}^{-1}$, $1656 \mathrm{~cm}^{-1}$ and $1653 \mathrm{~cm}^{-1}$, respectively [4]. While theoretical symmetric $\mathrm{SO}_{2}$ stretching frequencies are calculated at $1126.65 \mathrm{~cm}^{-1}$, experimental $\mathrm{SO}_{2}$ stretching vibrations are seen at 1161.63 $\mathrm{cm}^{-1}$ and $1169.24 \mathrm{~cm}^{-1}$. Theoretical asymmetric $\mathrm{SO}_{z}$ stretching frequencies were calculated at $1312.07 \mathrm{~cm}^{-1}$. The experimental asymmetric $\mathrm{SO}_{2}$ stretching vibrations were detected at 1307.86 $\mathrm{cm}^{-1}$ and $1278.92 \mathrm{~cm}^{-1}$. These values had been 
Table 4. Experimental and theoretical bond distances, bond angles and torsion angles $\left(\AA_{1}^{\circ}\right)$.

\begin{tabular}{|c|c|c|c|}
\hline Atoms & X-Ray & Theoretical & Error \\
\hline $\mathrm{C} 1-\mathrm{O} 4$ & $1.2472(18)$ & 1.2858 & -0.0386 \\
\hline $\mathrm{C} 1-\mathrm{N} 1$ & 1.3448 (19) & 1.3449 & -0.0001 \\
\hline $\mathrm{C} 1-\mathrm{C} 2$ & $1.455(2)$ & 1.4516 & 0.0034 \\
\hline $\mathrm{C} 2-\mathrm{C} 3$ & $1.326(2)$ & 1.3543 & -0.0283 \\
\hline $\mathrm{C} 3-03$ & $1.3862(18)$ & 1.3548 & 0.0314 \\
\hline $\mathrm{C} 3-\mathrm{C} 4$ & $1.477(2)$ & 1.4948 & -0.0178 \\
\hline Mg1-05i & $2.0445(11)$ & 2.1456 & -0.1011 \\
\hline Mg1-O5 & $2.0445(11)$ & 2.1055 & -0.0610 \\
\hline Mg1-06i & $2.0644(12)$ & 2.1006 & -0.0362 \\
\hline Mg1-06 & $2.0644(12)$ & 2.119 & -0.0546 \\
\hline Mg1-07i & $2.0817(12)$ & 2.117 & -0.0353 \\
\hline Mg1-O7 & $2.0817(12)$ & 2.099 & -0.0173 \\
\hline $\mathrm{N} 1-\mathrm{S} 1$ & $1.5648(13)$ & 1.6228 & -0.0580 \\
\hline O1-S1 & $1.4224(13)$ & 1.4516 & -0.0292 \\
\hline $\mathrm{O} 2-\mathrm{S} 1$ & $1.4224(14)$ & 1.4578 & -0.0354 \\
\hline O3-S1 & $1.6064(12)$ & 1.7325 & -0.1261 \\
\hline O4-C1-N1 & 119.52 (13) & 117.4629 & 2.0571 \\
\hline O4-C1-N1 & $119.52(13)$ & 117.4629 & 2.0571 \\
\hline $\mathrm{N} 1-\mathrm{C} 1-\mathrm{C} 2$ & $119.92(13)$ & 122.9148 & -2.9948 \\
\hline $\mathrm{C} 3-\mathrm{C} 2-\mathrm{C} 1$ & $123.00(14)$ & 122.0115 & 0.9885 \\
\hline $\mathrm{C} 2-\mathrm{C} 3-\mathrm{O} 3$ & $121.01(13)$ & 123.0256 & -2.0156 \\
\hline $\mathrm{C} 2-\mathrm{C} 3-\mathrm{C} 4$ & 127.88 (15) & 125.2354 & 2.6446 \\
\hline $\mathrm{O} 3-\mathrm{C} 3-\mathrm{C} 4$ & $111.11(13)$ & 111.7168 & -0.6068 \\
\hline 05i-Mg1-05 & $180.00(7)$ & 174.654 & 5.3460 \\
\hline $05 i-M g 1-06 i$ & 90.78 (5) & 82.6229 & 8.1571 \\
\hline $05-M g 1-06 i$ & $89.22(5)$ & 102.6819 & -13.4619 \\
\hline 05i-Mg1-06 & $89.22(5)$ & 82.9244 & 6.2956 \\
\hline 05-Mg1-06 & $90.78(5)$ & 91.7345 & -0.9545 \\
\hline 06i-Mg1-06 & $180.00(11)$ & 164.858 & 15.142 \\
\hline 05i-Mg1-07i & $88.59(5)$ & 87.9714 & 0.6186 \\
\hline 05-Mg1-07i & $91.41(5)$ & 91.5257 & -0.1157 \\
\hline 06i-Mg1-07i & $90.80(5)$ & 87.9752 & 2.8248 \\
\hline 06-Mg1-07i & $89.20(5)$ & 87.0229 & 2.1771 \\
\hline 05i-Mg1-07 & $91.41(5)$ & 94.7096 & -3.2996 \\
\hline
\end{tabular}


Table 4. Experimental and theoretical bond distances, bond angles and torsion angles $\left(\AA_{1}^{\circ}\right)$ (Continue).

\begin{tabular}{|c|c|c|c|}
\hline 05-Mg1-07 & $88.59(5)$ & 85.3799 & 3.2101 \\
\hline $06 i-M g 1-07$ & $89.20(5)$ & 96.8848 & -7.6848 \\
\hline 06-Mg1-07 & $90.80(5)$ & 88.7785 & 2.0215 \\
\hline 07i-Mg1-O7 & $180.00(9)$ & 174.708 & 5.2920 \\
\hline $\mathrm{C} 1-\mathrm{N} 1-\mathrm{S} 1$ & $119.71(10)$ & 120.0601 & -0.3501 \\
\hline $\mathrm{C} 3-03-\mathrm{S} 1$ & $117.39(9)$ & 118.0919 & -0.7019 \\
\hline $\mathrm{O} 1-\mathrm{S} 1-02$ & $116.30(9)$ & 120.0263 & -3.7263 \\
\hline $\mathrm{O} 1-\mathrm{S} 1-\mathrm{N} 1$ & $110.26(8)$ & 110.5333 & -0.2733 \\
\hline O2-S1-N1 & $112.79(8)$ & 112.1907 & 0.5993 \\
\hline $\mathrm{O} 1-\mathrm{S} 1-\mathrm{O} 3$ & $103.55(8)$ & 103.5388 & 0.0112 \\
\hline $\mathrm{O} 2-\mathrm{S} 1-\mathrm{O} 3$ & $106.37(8)$ & 104.4441 & 1.9259 \\
\hline $\mathrm{N} 1-\mathrm{S} 1-\mathrm{O} 3$ & $106.61(7)$ & 104.2713 & 2.3387 \\
\hline $\mathrm{O} 4-\mathrm{C} 1-\mathrm{C}_{2}-\mathrm{C} 3$ & $-172.61(16)$ & -168.5696 & -4.0404 \\
\hline $\mathrm{N} 1-\mathrm{C} 1-\mathrm{C} 2-\mathrm{C} 3$ & $5.9(2)$ & 8.1742 & -2.2742 \\
\hline $\mathrm{C} 1-\mathrm{C} 2-\mathrm{C} 3-\mathrm{O} 3$ & $-1.1(2)$ & -3.9296 & 2.8296 \\
\hline $\mathrm{C} 1-\mathrm{C} 2-\mathrm{C} 3-\mathrm{C} 4$ & $178.22(16)$ & 174.2134 & 4.0066 \\
\hline $\mathrm{O} 4-\mathrm{C} 1-\mathrm{N} 1-\mathrm{S} 1$ & $-166.15(12)$ & -170.2983 & 4.1483 \\
\hline $\mathrm{C} 2-\mathrm{C} 1-\mathrm{N} 1-\mathrm{S} 1$ & $15.4(2)$ & 12.8941 & 2.5059 \\
\hline $\mathrm{C} 2-\mathrm{C} 3-\mathrm{O} 3-\mathrm{S} 1$ & $-23.3(2)$ & -18.9379 & -4.3621 \\
\hline $\mathrm{C} 4-\mathrm{C} 3-\mathrm{O} 3-\mathrm{S} 1$ & $157.26(12)$ & 162.6946 & -5.4346 \\
\hline $\mathrm{C} 1-\mathrm{N} 1-\mathrm{S} 1-\mathrm{O} 1$ & $-146.67(14)$ & -140.7135 & -5.9565 \\
\hline $\mathrm{C} 1-\mathrm{N} 1-\mathrm{S} 1-\mathrm{O} 2$ & $81.47(15)$ & 82.4112 & -0.9412 \\
\hline $\mathrm{C} 1-\mathrm{N} 1-\mathrm{S} 1-\mathrm{O} 3$ & $-34.91(15)$ & -30.0292 & -4.8808 \\
\hline $\mathrm{C} 3-03-\mathrm{S} 1-01$ & $155.09(12)$ & 149.0736 & 6.0164 \\
\hline $\mathrm{C} 3-03-\mathrm{S} 1-02$ & $-81.83(13)$ & -84.5189 & 2.6889 \\
\hline $\mathrm{C} 3-\mathrm{O} 3-\mathrm{S} 1-\mathrm{N} 1$ & $38.76(13)$ & 33.3828 & 5.3772 \\
\hline
\end{tabular}

reported at $1195 \mathrm{~cm}^{-1}$ for $\left[\mathrm{Co}(\mathrm{acs})_{2}\left(\mathrm{H}_{2} \mathrm{O}\right)_{4}\right]$ and 1194 $\mathrm{cm}^{-1}$ for $\left[\mathrm{Ni}(\mathrm{acs})_{2}\left(\mathrm{H}_{2} \mathrm{O}\right)_{4}\right.$ ] [4]. The theoretical $\mathrm{C}-\mathrm{O}$ and $\mathrm{S}-\mathrm{O}$ stretching frequencies were calculated at $940.76 \mathrm{~cm}^{-1}$ and $653.58 \mathrm{~cm}^{-1}$, respectively. The experimental spectrums belong to these stretching vibrations were found at $1073.27 \mathrm{~cm}^{-1}$ and $841.73 \mathrm{~cm}^{-1}$, respectively.

\section{Thermal Analysis}

TG, DTG and DTA plots and significant degradation steps for $\left[\mathrm{Mg}\left(\mathrm{H}_{2} \mathrm{O}\right)_{6}\right]$ (acs) ${ }_{2}$ complex are given by Figure 7. The first step of the thermal analysis plot of $\left[\mathrm{Mg}\left(\mathrm{H}_{2} \mathrm{O}\right)_{6}\right](\mathrm{acs})_{2}$ complex is the removal of hydrated water (as moisture).

At first step corresponding to the temperature range of $0-95.42^{\circ} \mathrm{C}$, approximately 1 mole of water is removed (Experimental: 3.29\%, Theoretical: 3.94\%). Subsequent 3 steps are deaquation. The first step of deaquation is observed at the temperature range of $95-164^{\circ} \mathrm{C}$ by the weight loss of $8.22 \%$. This loss is due to the removal of 2 moles of aqua ligands (Theoretical: $7.88 \%$ ).

$8.18 \%$ weight loss observed at the temperature range of $164-213^{\circ} \mathrm{C}$ is the second 


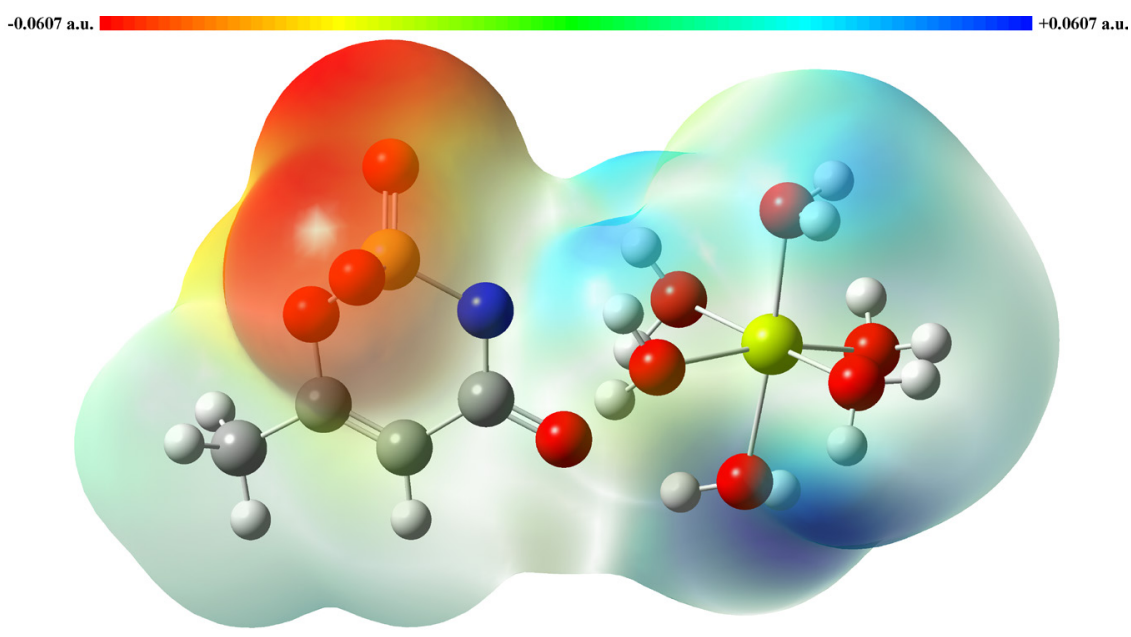

Figure 5. Molecular electrostatic potential map at the B3LYP/6-31G(d,p) level.

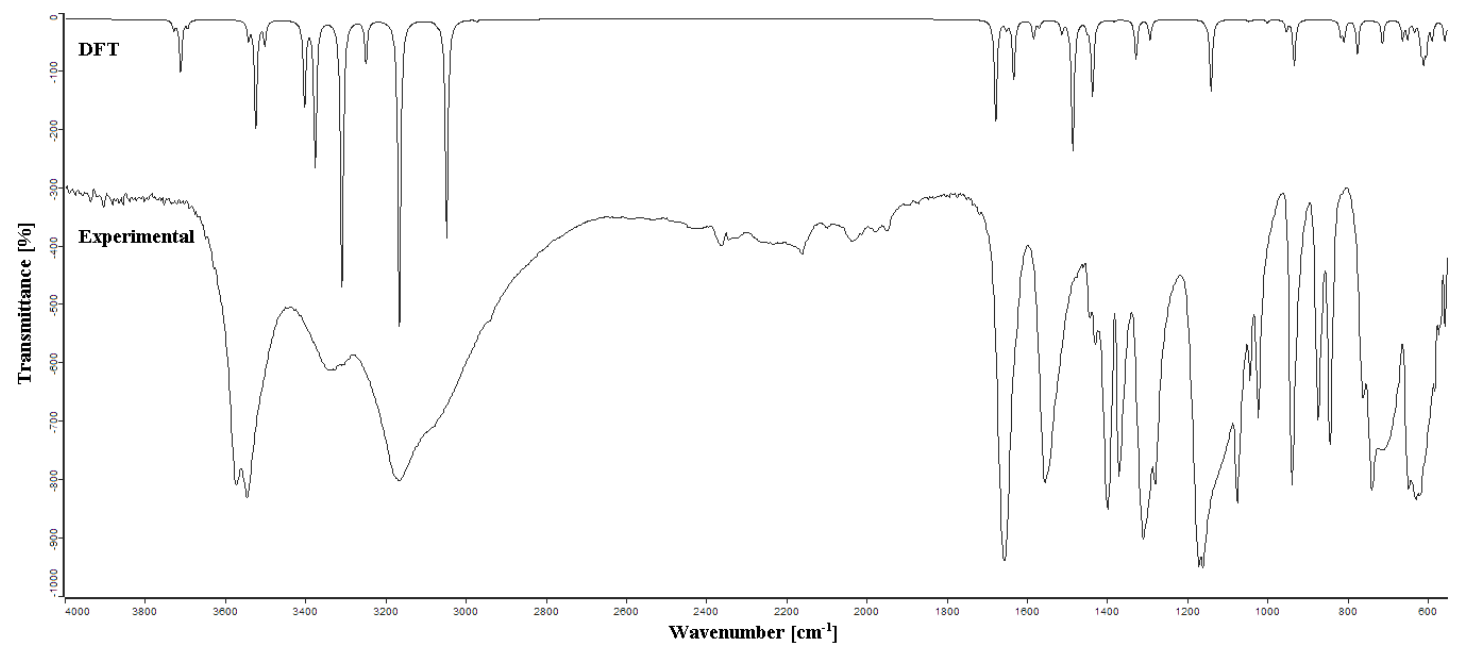

Figure 6. The theoretical and experimental spectrum of the title compound.

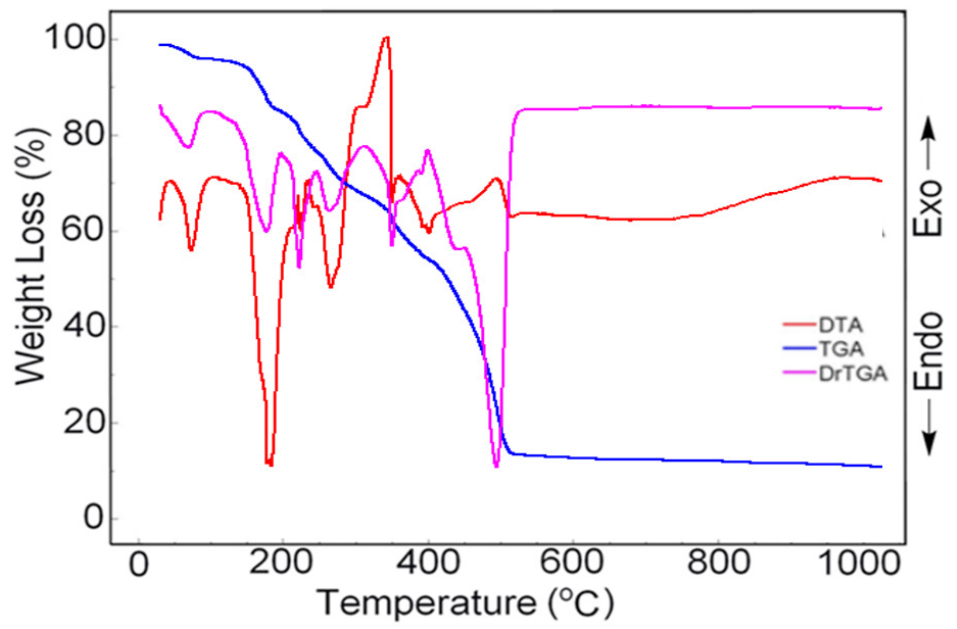

Figure 7. The TG, DTG and DTA curves of the $\left[\mathrm{Mg}\left(\mathrm{H}_{2} \mathrm{O}\right)_{6}\right](\mathrm{acs})_{2}$ complex. 
Table 5. Thermoanalytical results (TG-DTG/DTA) for the metal complexes.

\begin{tabular}{|c|c|c|c|c|c|c|c|c|c|c|}
\hline \multirow{2}{*}{\multicolumn{2}{|c|}{$\begin{array}{c}\text { Complex } \\
\mathrm{C}_{8} \mathrm{H}_{20} \mathrm{MgN}_{2} \mathrm{O}_{14} \mathrm{~S}_{2}\end{array}$}} & \multirow[t]{2}{*}{$\begin{array}{c}\text { Temp. } \\
\text { Range/C }\end{array}$} & \multirow[t]{2}{*}{$\begin{array}{c}\mathrm{DTA}_{\max } / \\
{ }^{\circ} \mathrm{C}\end{array}$} & \multirow[t]{2}{*}{$\begin{array}{l}\text { Removed } \\
\text { Group }\end{array}$} & \multicolumn{2}{|c|}{$\begin{array}{c}\text { Weight } \\
\text { Change/\% }\end{array}$} & \multicolumn{2}{|c|}{ Total Loss/\% } & \multirow[t]{2}{*}{$\begin{array}{c}\text { Decom. } \\
\text { Prod. }\end{array}$} & \multirow{2}{*}{$\begin{array}{l}\text { Colour } \\
\text { White }\end{array}$} \\
\hline & & & & & Found & Calc. & Found & Clac. & & \\
\hline & 1 & $45-65$ & 55 & $2 / 3 \mathrm{H}_{2} \mathrm{O}^{*}$ & 2.46 & 2.63 & & & & \\
\hline & 2 & $97-174$ & 166 & $2 \mathrm{H}_{2} \mathrm{O}$ & 7.57 & 7.01 & & & & \\
\hline & 3 & $176-220$ & 211 & $2 \mathrm{H}_{2} \mathrm{O}$ & 7.12 & 7.01 & & & & \\
\hline & 4 & $232-282$ & 251 & $2 \mathrm{H}_{2} \mathrm{O}$ & 6.74 & 7.01 & & & & \\
\hline & 5 & $290-352$ & -315.335 & $\mathrm{SO}_{2}$ & 14.43 & 14.02 & & & & \\
\hline & 6 & $354-429$ & 385 & $\mathrm{SO}_{2}$ & 13.65 & 14.02 & & & & \\
\hline & 7 & $430-523$ & 448.498 & $\mathrm{C}_{4} \mathrm{H}_{4} \mathrm{NO}_{2^{\prime}} \mathrm{C}_{4} \mathrm{H}_{4} \mathrm{~N}$ & 38.77 & 39.41 & 9.26 & 8.89 & $\mathrm{MgO}$ & Gray \\
\hline
\end{tabular}

step of deaquation. Also at this stage, $2 \mathrm{~mol}$ of aqua ligand are removed (Theoretical $7.88 \%$ ).

The final step of deaquation is occurred at the temperature range of $213-256^{\circ} \mathrm{C}$. Weight loss of $8.04 \%$ corresponds to removal of 2 moles of aqua ligand. After this step, it is considered that $\mathrm{Mg}$ (acs) ${ }_{2}$ is formed.

An exothermic weight loss of $14.13 \%$ is observed at the temperature range of 290$352^{\circ} \mathrm{C}$. This loss corresponds to removal of $\mathrm{SO}_{2}$ due to the decomposition of one of acs ligands (Theoretical: $14.01 \%$ ). At $354-429^{\circ} \mathrm{C}$, there is also an exothermic mass loss of $13.934 \%$ observed. This is the decomposition of the other acs ligands and $\mathrm{SO}_{2}$ removal. It is thought that endothermic mass loss of $38.77 \%$ occurred at the temperature range of $430-523^{\circ} \mathrm{C}$ is because of the removal of organic residue formed as a result of the decomposition of organic ligands. Remaining $\mathrm{MgO}$ as a decomposition product is determined by infrared spectroscopy. Our idea is supported by that experimental residue amounts investigated are in accordance with the theoretical values (exp.: 9.26\% - calc.: $8.89 \%)$. DTG plot shows that aqua ligands are removed step by step as stated above. The color of last decomposition product is grayish because of not fully completed combustion depending on analysis to be carried out in an inert nitrogen atmosphere and remaining carbonized carbon on the surface of residue product.
The thermal decomposition steps, removed products and decomposition temperature range of both of are summarized at Table 5 .

The crystal structure data show that the $\left[\mathrm{Mg}\left(\mathrm{H}_{2} \mathrm{O}\right)_{6}\right](\mathrm{acs})_{2}$ complex has three different aqua ligands having different bond lengths $[\mathrm{Mg}$ $\mathrm{O}\left(\mathrm{H}_{2} \mathrm{O}\right): 2.0445$ (11) $\AA$, 2.0644 (12) $\AA$, 2.0817 (12) $\AA]$. The deaquation process of the $\left[\mathrm{Mg}\left(\mathrm{H}_{2} \mathrm{O}\right)_{6}\right]$ (acs) ${ }_{2}$ complex occurs at three steps that agree with the crystal data.

\section{Mass Analysis}

The thermal decomposition pathway of the $[\mathrm{Mg}(\mathrm{H} 2 \mathrm{O}) 6](\mathrm{C} 4 \mathrm{H} 4 \mathrm{NO} 4 \mathrm{~S}) 2$ complex was recorded using direct insertion probe pyrolysis mass spectrometry method (Figure 8). The thermal decomposition pathway of the $\left[\mathrm{Mg}\left(\mathrm{H}_{2} \mathrm{O}\right)_{6}\right]$ $\left(\mathrm{C}_{4} \mathrm{H}_{4} \mathrm{NO}_{4} \mathrm{~S}\right)_{2}$ complex was recorded using direct insertion probe pyrolysis mass spectrometry method (Figure 8). The mass spectra show the fragmentation pattern and the most fragile points of the molecule. The molecular ion peaks in the mass spectra recorded were detected at the 455.55. Beside the most abundant peaks, much fewer abundant peaks observed on the spectra depend probably on the nature of ligands.

\section{Conclusion}

The hexaaquamagnesium(II) acesulfamate complex consists of $\left[\mathrm{Mg}\left(\mathrm{H}_{2} \mathrm{O}\right)_{6}\right]_{2+}$ dication and (acs) ${ }^{-}$anion. In the crystal structure, $\left[\mathrm{Mg}\left(\mathrm{H}_{2} \mathrm{O}\right)_{6}\right]^{2+}$ dications and (acs) ${ }^{-}$anions have been linked 


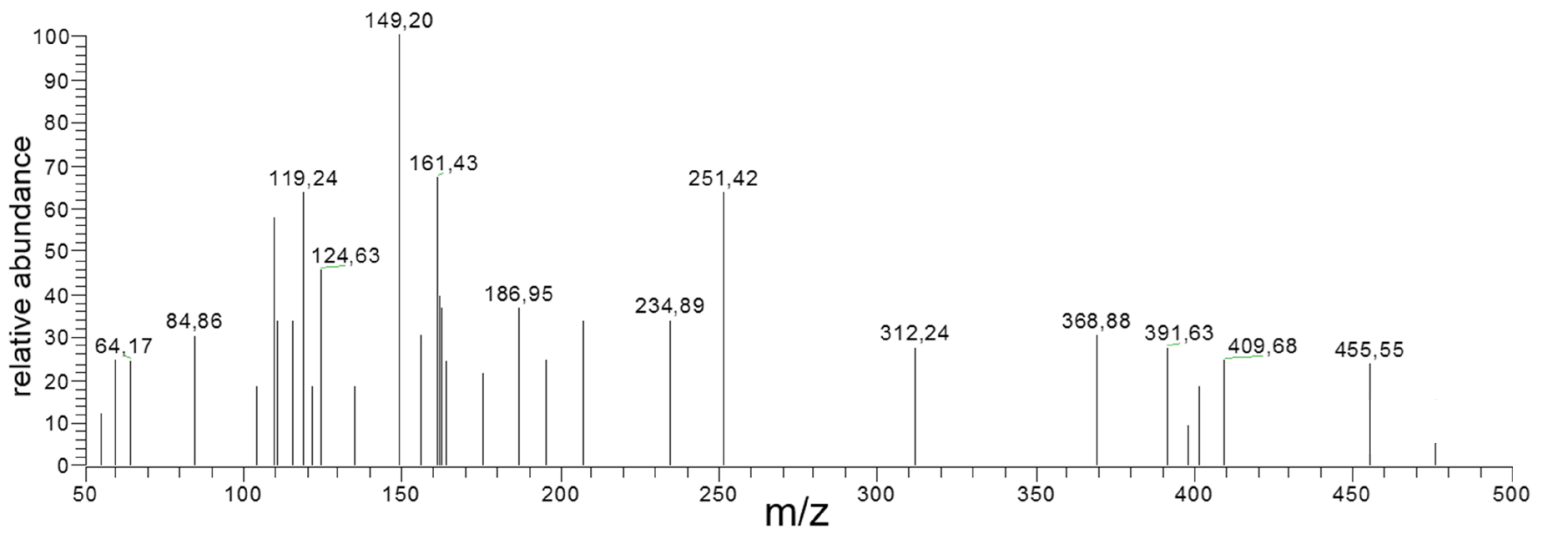

Figure 8. Solid Probe GC-Mass Spectroscopy pattern of $\left.\mathrm{Mg}\left(\mathrm{H}_{2} \mathrm{O}\right)_{6}\right]\left(\mathrm{C}_{4} \mathrm{H}_{4} \mathrm{NO}_{4} \mathrm{~S}\right)_{2}$ complex.

through $\mathrm{O}-\mathrm{H} \cdots \mathrm{O}$ hydrogen bonds. The geometric parameters obtained by $\mathrm{x}$-ray diffraction are very close to the theoretical geometric parameters for magnesium complex.

The environment of $\mathrm{Mg}^{2+}$ ion with coordinated six aqua ligands has distorted octahedron geometry. The energy gap between HOMO and LUMO has found $1.3984 \mathrm{eV}$ for magnesium complex with B3LYP/6-31G(d,p).

As shown at MEP, while the electrophilic attack centers of this complex are at the environment of sulfonyl oxygen, the nucleophilic attack centers are at the environment of hydrogen atoms belong to aqua ligands. The intermolecular hydrogen bonds are shown at these regions from information obtained by x-ray diffraction.

The vibrational frequencies belong to magnesium complex show some deviation from other reported crystal structures [4], because of different molecular geometry. The reason of difference between theoretical and experimental values may be hydrogen bonds and different geometric parameters between experimental and theoretical structure.

Thermal analysis of the complex is compatible with the structure determined by X-ray technique. The six aqua ligands decompose with three stages from molecule. At the last, $\mathrm{SO}_{2}$ group release from complex and final product, $\mathrm{MgO}$, remains left over from behind [32-34].

\section{ACKNOWLEDGEMENTS}

The authors thank the Hitit University Research Fund (Project No: FEF03.12.06) and Ondokuz Mayıs University Research Fund (Project No: PYO.FEN.1904.09.006) for financial support of this project.

\section{References}

1. V.D. Duffy and G. H. Anderson, Position of the American Dietetic Association: use of nutritive and nonnutritive sweeteners, J. Am. Diet. Assoc., 98 (1998) 580-587.

2. W.L. Hough-Troutman, M. Smiglak, S. Griffin, W.M. Reichert, I. Mirska, J. Jodynis-Liebert, T. Adamska, J. Nawrot, M. Stasiewicz, R.D. Rogers, J. Pernak, Ionic liquids with dual biological function: sweet and antimicrobial, hydrophobic quaternary ammonium-based salts, New J. Chem., 33 (2009) 26-33.

3. P. Nockemann, B. Thijs, K. Driesen, C.R. Janssen, K.V. Hecke, L.V. Meervelt, S. Kossmann, B. Kirchner, K. Binnemans, Choline saccharinate and choline acesulfamate: Ionic liquids with low toxicities, J. Phys. Chem. B, 111 (2007) 5254-5263.

4. H. İçbudak, E. Adıyaman, N. Çetin, A. Bulut, O. Büyükgüngör, Synthesis, structural characterization and chromotropism of a $\mathrm{Ni}(\mathrm{II})$ and a $\mathrm{Co}$ (II) compound with acesulfamate as a ligand, Trans. Met. Chem., 31 (2006) 666-672.

5. S.P. Velaga, V.R. Vangala, S. Basavoju, D. Boström, Polymorphism in acesulfame sweetener: structureproperty and stability relationships of bending and brittle crystals, Chem. Commun., 46 (2010) 35623564.

6. B. Sirinivasan, S.Y. Shetgaonkar, C. Näther, W. Bensch, Solid state synthesis and characterization of a triple chain calcium(II) coordination polymer showing two different bridging 4-nitrobenzoate coordination modes, Polyhedron, 28 (2009) 534-540. 
7. R.J. Elin, Assessment of magnesium status, Clin. Chem., 33 (1987) 1965-1970.

8. J.R. Purvis, A. Movahed, Magnesium disorders and cardiovascular diseases, Clin. Cardiol., 15 (1992) 556568.

9. L.E. Rabbani, E.M. Antman, The role of magnesium therapy in acute myocardial infarction, Clin. Cardiol., 19 (1996) 841-844.

10. M.A. Ralston, M.R. Murnane, R.E. Kelley, R.A. Altschuld, D.V. Unverferth, C.V. Leier, Magnesium content of serum, circulating mononuclear cells, skeletal muscle, and myocardium in congestive heart failure, Circulation, 80 (1989) 573-580.

11. P. Lim, E. Jacob, Magnesium deficiency in patients on long-term diuretic therapy for heart failure., Brit. Med. J., 3 (1972) 620-622.

12. M.J. Frisch, G.W. Trucks, H.B. Schlegel, G.E. Scuseria, M.A. Robb, J.R. Cheeseman, J.A. Montgomery Jr. T. Vreven, K.N. Kudin, J.C. Burant, J.M. Millam, S.S. Iyengar, J. Tomasi, V. Barone, B. Mennucci, M. Cossi, G. Scalmani, N. Rega, G.A. Petersson, H. Nakatsuji, M. Hada, M. Ehara, K. Toyota, R. Fukuda, J. Hasegawa, M. Ishida, T. Nakajima, Y. Honda, O. Kitao, H. Nakai, M. Klene, X. Li, J.E. Knox, H.P. Hratchian, J.B. Cross, V. Bakken, C. Adamo, J. Jaramillo, R. Gomperts, R. E. Stratmann, O. Yazyev, A.J. Austin, R. Cammi, C. Pomelli, J.W. Ochterski, P.Y. Ayala, K. Morokuma, G. A. Voth, P. Salvador, J. . Dannenberg, V.G. Zakrzewski, S. Dapprich, A.D. Daniels, M.C. Strain, O. Farkas, D.K. Malick, A.D. Rabuck, K. Raghavachari, J.B. Foresman, J.V. Ortiz, Q. Cui, A. G. Baboul, S. Clifford, J. Cioslowski, B.B. Stefanov, G. Liu, A. Liashenko, P. Piskorz, I. Komaromi, R.L. Martin, D.J. Fox, T. Keith, M.A. Al-Laham, C. Y. Peng, A. Nanayakkara, M. Challacombe, P.M. W. Gill, B. Johnson, W. Chen, M.W. Wong, C. Gonzalez, J.A. Pople, Gaussian 03, Revision E.01, Gaussian Inc., Wallingford CT, 2004.

13. J.P. Merrick, D. Moran, L. Radom, An Evaluation of Harmonic Vibrational Frequency Scale Factors, J. Phys. Chem., A111 (2007) 11683-11700.

14. A. Frisch, R. Dennington, T. Keith, J. Millam, A. B. Nielsen, A.J. Holder, J. Hiscocks, GaussView Reference Version 40, Gaussian Inc., Pittsburgh, 2007.

15. Stoe \& Cie, X-AREA (Version 1.18) and X-RED32 (Version 1.04), Stoe \& Cie, Darmstadt, Germany 2002.

16. G.M. Sheldrick, A short history of SHELX, Acta Crystallogr., A, 64 (2008) 112-122.

17. L.J. Farrugia, ORTEP-3 for Windows - a version of ORTEP-III with a Graphical User Interface (GUI), J. Appl. Crystallogr., 30 (1997) 565.

18. L.J. Farrugia, WinGX suite for small-molecule singlecrystal crystallography, J. Appl. Crystallogr., 32 (1999) 837-838.

19. A.L. Spek, Structure validation in chemical crystallography, Acta Crystallogr., 65 (2009) 148-155.

20. O.E. Piro, G.A. Echeverría, B.S. Parajón-Costa, E.J. Baran, Structural and IR-spectroscopic characterization of magnesium acesulfamate, Zeitschrift für Naturforschung B., 71 (2016) 51.
21. J.F. Wen, W.Z. Yin, Y.X. Qiao, Diaquabis[1-ethyl-6fluoro-4-oxo-7 (piperazin-1-yl)-1,4-dihydroquinoline3carboxylato]magnesium(II) hexahydrate, Acta Crystallogr., E66 (2010) m1388.

22. B.S. Zhang, J.P. Qiu, L.H. Liu, W.Xu, Tetraaqua(2,2-bipyridine- $\kappa^{2} \quad \mathrm{~N}, \mathrm{~N}$ )magnesium(II) bis(4-fluorobenzoate), Acta Crystallogr., E66 (2010) m1624.

23. F. Huang, W.D. Song, Tetra-aqua-bis(1-hydr-oxy-2naphthoato- 02)magnesium(II) Acta Crystallogr., E64 (2008) m552.

24. A.Bulut,H.İçbudak,G.Sezer,C.Kazak, Bis(acesulfamatoк2N3,04)bis(2-aminopyrimidine-N1)copper(II), Acta Crystallogr., C61 (2005) m228-m230.

25. H. İçbudak, A. Bulut, N. Çetin, C. Kazak, Bis (acesulfamato)teraaquacobalt(II), Acta Crystallogr., 61 (2005) 1-3.

26. Z.S. Şahin, H. İ̧budak, Ş. Işık, Di- $\mu$-acesulfamato$3 \mathrm{~N}, \mathrm{O}: \mathrm{O} ; 3 \mathrm{O}: \mathrm{N}, \mathrm{O}-\mathrm{bis}[($ acesulfamato- $2 \mathrm{~N}, \mathrm{O})]$ bis (3methylpyridine)cadmium(II)], Acta Crystallogr., C65 (2009) 463-465.

27. H. İçbudak, A.Uyanık, A.Bulut, C. Arıcı, D.Ülkü, Synthesis, thermal, spectroscopic and structural properties of di(aqua)bis( $N, N$-dimethylethylenediamine- ${ }^{2} \mathrm{~N}, \mathrm{~N}$ ) copper(II) acesulfamate, Z. Kristallogr., 222 (2007) $432-436$

28. G. Demirtaş, N. Dege, H. İçbudak, Ö. Yurdakul, O. Büyükgüngör, Experimental and DFT studies

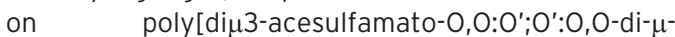
acesulfamato-O,O;N-di- $\mu$-aqua-dicalcium(II)] complex, J. Inorg. Organomet. Polym. and Materials, 22 (2012) 671-679.

29. F. Jensen, Introduction to Computational Chemistry, Second Edition, John Wiley and Sons., Chichester, 2007, Chapter 2.

30. W. Hussein, C.G. Walker, Z. Peralta-Inga, J.S. Murray, Computed electrostatic potentials and average local ionization energies on the molecular surfaces of some tetracyclines, Int. J. Quantum Chem. 2001, 82, 160-169.

31. B. Stuart, Infrared Spectroscopy: Fundamentals and Applications, John Wiley and Sons., Chichester, 2004, Chapter 3.

32. D. A. Köse, F. Akkurt, O. Şahin, O. Büyükgüngör, Synthesis and Structural Characterization of a Binuclear Mixed-Ligand (Salicylate and N,Ndiethylnicotinamide) Nickel(II) Complex, Its Magnetic Properties. $\left[\mathrm{Ni}_{2}(\mu \text {-Sal })_{4}(\text { Dena })_{2}\right] \mathrm{H}_{2} \mathrm{O}, \mathrm{J}$. Chinese Chem. Soc., 61 (2014) 1326-1332.

33. D.A. Köse, E. Toprak, A. Kaşarcı, E. Avcl, G.A. Avcl, O. Şahin, O. Büyükgüngör, ynthesis, Spectral, Thermal Studies of $\mathrm{Co}(\mathrm{II}), \mathrm{Ni}(\mathrm{II}), \mathrm{Cu}(\mathrm{II})$ and $\mathrm{Zn}(\mathrm{II})$-arginato Complexes. Crystal Structure

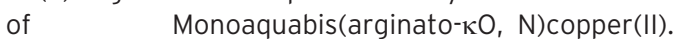
$\left[\mathrm{Cu}(\mathrm{arg})_{2}\left(\mathrm{H}_{2} \mathrm{O}\right)\right] \cdot \mathrm{NaNO}_{3}$ J. Chinese Chem. Soc., 61 (2014) 881-890.

34. O. Yurdakul, D.A. Köse, Mixed Ligand Complexes of Acesulfame/Nicotinamide with Earth Alkaline Metal Cations Mgll, Call, Ball and Srll. Synthesis and Characterization, Hittite J. Science and Engineering, 1 (2014) 51-57. 